\begin{tabular}{|l|l|l||}
\hline \multicolumn{2}{|c|}{ PublisherInfo } \\
\hline \hline PublisherName & $:$ & Palgrave Macmillan UK \\
\hline \hline PublisherLocation & $:$ & London \\
\hline \hline PublisherImprintName & $:$ & Palgrave Macmillan \\
\hline
\end{tabular}

\title{
Economic Review, November 2007
}

\begin{tabular}{||l|l|l||}
\hline \multicolumn{2}{|c||}{ ArticleInfo } \\
\hline \hline ArticleDOI & $:$ & 10.1057 /palgrave.elmr.1410166 \\
\hline \hline ArticleCategory & $:$ & Economic Review \\
\hline \hline ArticleFirstPage & $:$ & 6 \\
\hline \hline ArticleLastPage & $:$ & 14 \\
\hline \hline & $:$ & $\begin{array}{l}\text { RegistrationDate }: 2007-11-16 \\
\text { OnlineDate } \quad: 2007-11-16\end{array}$ \\
ArticleHistory & $:$ & Crown copyright2007 \\
\hline \hline ArticleCopyright &
\end{tabular}


Anis Chowdhury, ${ }^{\text {Aff1 }}$

Aff1 Office for National Statistics

\section{Monthly review of economic and labour market trends in the UK.}

GDP continued to grow robustly in 2007 quarter three, driven by a pick up in services sector output but offset by lower manufacturing output. On the expenditure side in 2007 quarter two, business investment and household spending strengthened. The current account deficit narrowed in 2007 quarter two. The trade deficit narrowed in 2007 quarter two and showed signs of further narrowing in quarter three. The labour market remains buoyant but average earnings remain relatively subdued. The public sector finances position deteriorated in September 2007. Consumer price inflation was unchanged in September. Producer output price inflation was unchanged in September, but still exhibited signs of upward pressure.

Misc

The Full Text of this article can be found on the National Statistics website (http://www.statistics.gov.uk/downloads/theme_economy/EconReview_1107.pdf). 